\title{
The Development and Functional Regulation of the Fetal Adrenal Cortex
}

\author{
Xiulan Yang, Yun Zhen, Lian Liu* \\ Department of Pharmacology, Medical School of Yangtze University, Jingzhou, China \\ Email: 406490115@qq.com, *liulian@yangtzeu.edu.cn
}

How to cite this paper: Yang, X.L., Zhen, Y. and Liu, L. (2020) The Development and Functional Regulation of the Fetal Adrenal Cortex. Yangtze Medicine, 4, 254-276. https://doi.org/10.4236/ym.2020.44024

Received: October 9, 2019

Accepted: September 27, 2020

Published: September 30, 2020

Copyright $\odot 2020$ by author(s) and Scientific Research Publishing Inc. This work is licensed under the Creative Commons Attribution-NonCommercial International License (CC BY-NC 4.0). http://creativecommons.org/licenses/by-nc/4.0/

\begin{abstract}
As an important endocrine organ of the human, the adrenal cortex is responsible for the synthesis of various steroids. It is important to maintain pregnancy, promote fetal growth and nervous system development. Moreover, it is also important for the growth and development of the fetus after birth. Abnormal functional development of the adrenal cortex will induce the abnormal synthesis of steroid hormones and trigger the occurrence of related diseases. In this review, we discuss the morphological and functional development of fetal adrenal cortex and its regulatory factors in humans and rodents.
\end{abstract}

\section{Keywords}

The Fetal Adrenal Cortex, Steroid Hormones, Growth Factor, Transcription Factor, Placental Hormone

\section{Introduction}

It is known that the adrenal glands include outer cortex and inner medulla, which come from different embryonic development layers respectively. Medulla cells come from nerve ectoderm and cortex comes from mesoderm tissue, which has different physiological functions. As an important endocrine organ of the human body, the adrenal gland is responsible for the synthesis of various steroid hormones. It is of great significance to maintain pregnancy and promote fetal growth and nervous system development. Moreover, it is also important for the growth and development of the fetus after birth. Therefore, the normal development of the adrenal gland during the fetal period is the key to determine the maturation and destiny of the fetus [1] [2] [3] [4]. Abnormal development of the adrenal cortex can lead to metabolic disorders of electrolytes and carbohydrates, leading to circulatory failure, hypoglycemic coma and death. 


\section{The Development of Adrenal Glands}

\subsection{The Development of Adrenal Cortical Morphology}

The adrenal glands are a pair of organs located adjacent to the superior pole of each kidney. The left adrenal gland is half-moon and the right adrenal gland is triangular. The adrenal cortex is thicker and is located in the outer layer of the adrenal cortex, which accounts for about $80 \%$ of the adrenal gland. It can be divided into three parts: the zona glomerulosa $(\mathrm{zG})$, the zona fasciculata $(\mathrm{zF})$ and the zona reticularis $(\mathrm{zR})$. Cortical hormones secreted by the adrenal cortex are classified into three categories, namely, salt corticosteroids, glucocorticoids and sex hormones [5]. All kinds of cortical hormones are secreted by epithelial cells of different layers of adrenal cortex: and the globular band cells secrete saline corticosteroids, which are mainly aldosterone; the middle zona fasciculata produce glucocorticoids, which are mainly cortisol; and the innermost zona reticularis contains a network of cells that synthesize sex steroid hormones such as dehydroandrosterone and estradiol, also secrete a small amount of glucocorticoids [6] [7].

\subsubsection{Human}

The landmark study of human adrenal cortex development began in the 1960s [8]. The urinary genital ridge and the body cavity between the epithelial membrane epithelium is gathered themselves together at about the fourth week of gestation, and then the proliferation, migration, formed in the kidney area in the cells, called adrenal blastema, which is the first to recognize the adrenal gland. By the eighth week of gestation, the adrenal rudiment has been formed, with the fetal zone and the definitive zone [9]. At around the ninth week of gestation, the adrenal blastemais are completely enclosed by the adrenal capsule, which are composed of specialized mesenchymal cells migrating from the area of Bowman's capsule. At the same time, an extensive network of sinusoidal capillaries develops between the cords of the fetal zone. This vasculature predominates in the central portion of the fetal zone and persists throughout fetal life. Consequently, the adrenal cortex is one of the most highly vascularized organs in the primate fetus. Abundant vascularization is likely required to facilitate access of hormonal products to the circulation. The adrenal cortex is further differentiated, and the fetal zone is dominant in the 16th - 20th weeks of gestation. It is composed of a large number of eosinophilic cells and is typical of the morphology of steroid secretory cells. The outside of the fetal zone is the definitive zone, which is composed of a narrow band of small tightly packed basophilic cells that exhibit structural characteristics typical of cells in a proliferative state. With the development of pregnancy, the lipid droplets in the permanent cells gradually increased and began to have the characteristics of steroid secretory cells, with the characteristics of adult adrenocortical globules at 30 weeks [10] [11]. In the midgestation, the transition zone may have the capacity to synthesize cortisol and thus be analogous to cells of the zona fasciculata of the adult adrenal [1]. By 
the 30th week of gestation, the transitional zone began to take on the appearance of the zona fasciculata [8]. After birth, the fetal band begins to atrophy and degenerates into the reticularis zona, While the fetal cell apoptosis, the definitive zone and the transitional zone proliferate and thicken, however, until the age of 10 to 20 , the adrenal cortex is gradually mature and has the characteristics of mature adrenal cells.

To sum up, the morphological development of adrenal gland can be divided into five main stages [8]: 1) 3 - 4 weeks of gestation, condensation of the celomic epithelium; 2) 4 - 6 weeks of gestation, the proliferation and migration of coelomic epithelium; 3) Between 8 - 10 weeks of gestation, the fetal adrenal cortical cells differentiated into the fetal zone and the definitive zone; 4) In the first 3 months after birth, the fetal band degeneration disappeared; 5) From 10 to 20 years old, the adult adrenal band is established and mature. It can be seen that the development of adrenal glands begins in the embryo and continues into adulthood.

\subsubsection{Rodent}

The development of adrenal cortical cells in rodents is different from that of human beings, but the basic development process and genes that play an important role in development are basically consistent [12]. The development of the adrenal cortex of rodents also begins with the migration of the epithelial cells of the urinary reproductive ridge, which occurs in the 9th day of embryo formation. In embryo 10.5 days, adrenal cortical cell differentiation [13]. Mouse embryos 12 - 14 days, rat embryos 15 days, neural crest cells begin to migrate into the fetal band, establish adrenal medullary [14] [15] [16]. There is a gender difference in fetal band degeneration in mice, male degeneration occurs in adolescence, and females occur in pre-pregnancy [12].

There is a slight difference between adrenal growth in rats and mice. In the late 1950s, Roos [17] suggested that the rat's adrenal glands had appeared in 18 days, and histology is similar to adult adrenal glands. This phenomenon has been reported in other laboratories as well [16]. Also not found in the development of adrenal gland of rats with fetus, and the results suggest that exist in the rat adrenal gland and zoning, called Undifferentiated belt (Undifferentiated Zone), the belt does not express steroid enzyme, preliminary considered by the differentiation of the centrality of migration, and maintain the adrenal cortex function, may be the stem cells [18]. It has been reported that the undifferentiated zone cells and surrounding cells are stem cells/derived cells of the rat adrenal cortex, maintaining the functional zoning of the adrenal cortex. There is the Sonic hedgehog (Shh), an important factor in embryonic development and adult stem cell maintenance, exists in $\mathrm{zU}$ of the rat adrenal gland and the Shh containing cells seem to migrate bidirectionally [19].

\subsection{The Functional Development of the Adrenal Gland}

The adrenal cortex produces a series of steroid hormones (as shown in Figure 1) 


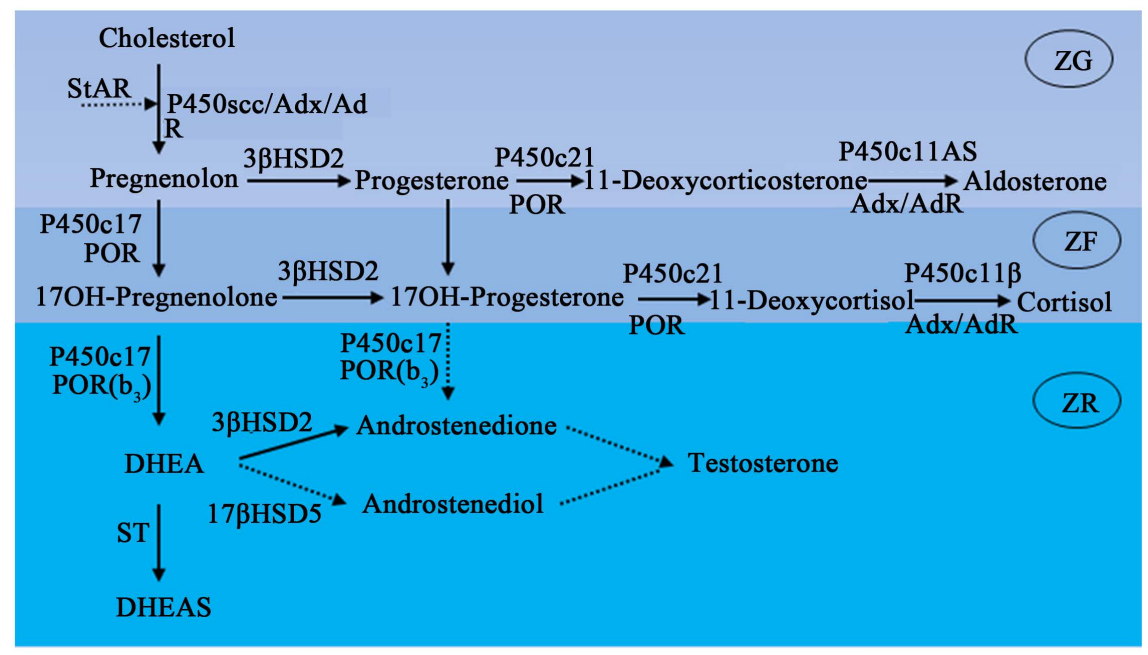

Figure 1. Adrenal steroid hormone synthesis in the human [20]: zona, ZF, zona fasciculata, ZR: mesh belt, Adx: adrenocortical iron oxide reduction protein, AdR: adrenocortical iron oxide reduction reductase, protein FOR: P450 oxidoreductase, ST: sulfuryl transferase.

[20], any changes in the expression of these steroidal synthase will lead to abnormal synthesis of adrenal steroid and related diseases [20] [21]. Dehydroepiandrosterone (DHEA) and cortisol are the main steroids produced by the adrenal glands of early pregnancy [1]. Cholesterol is a precursor of the synthesis of steroid hormone, cholesterol is absorbed by the body, the first is the synthesis of steroid hormones in acute regulatory proteins (steroidogenic acute regulation protein, StAR) to the mitochondrial membrane, Cholesterol P450 side chain cleavage enzyme (cytochrome P450, P450scc) is converted to progesterone. Pregnenolone is $17 \alpha$-hydroxylase (17 $\alpha$-hydroxylase/17,20-lyase, P450c17) hydroxyl into $17 \alpha$-hydroxy pregnenolone (17 $\alpha$-OH-pregnenolone, $17 \alpha \mathrm{OH}$ Preg), by 3-hydroxy beta steroid dehydrogenase ( 3 beta-hydroxysteroid dehydrogenase, 3 beta HSD) into 17 alpha hydroxy progesterone, is 17,20-lyase cracking, come in further formation of dehydroepiandrosterone sulfate (DHEAS). Or, progesterone is metabolized by 3 beta-hsd, and then 17 alpha-hydroxylated progesterone. In the end, 17 alpha-hydroxyprogesterone was metabolized by 21-hydroxygenase (steroid 21-hydroxylase, P450c21), 11 beta-hydroxylase (steroid 11 beta-hydroxylase, $\mathrm{P} 450 \mathrm{c} 11$ ). It can be seen that the related enzymes involved in the synthesis of adrenal steroid hormones include: StAR, P450scc, P450c17, 3 beta-HSD, P450c21 and P450c11. For rats, because the adrenal glands do not express $\mathrm{P} 450 \mathrm{c} 17$, the progesterone can be converted to progesterone directly from 3 beta-hsd to progesterone, which is catalyzed by P450c21 and P450c11 to produce corticosterone. In both humans and animals, P450scc and StAR are both speed limit enzymes, regulating the speed of steroid synthesis [22].

\subsubsection{Human}

The human fetal adrenal cortex has steroidogenic capabilities early in gestation. 
This is first seen at 6 - 8 weeks when the cells in the adrenal blastema differentiate and acquire steroidogenic characteristics [10], In about 8 - 10 weeks of gestation, the fetal adrenal cortex produce a large number of precursor of estriol--DHEA-S, and in the 12th week of pregnancy, there is a significant increase in the concentration of estrogen in the maternal blood circulation [23]. The study confirmed that the fetal adrenal glands were able to express the enzymes needed to synthesize cortisol during the 7 - 10 weeks of gestation [24]. Observations of infants with congenital adrenal hyperplasia (CAH)suggest that the fetal adrenal cortex produces cortisol in about 8 - 9 weeks of gestation under the regulation of adrenocorticotropic hormone (adrenocorticotrophic hormone, ACTH) [25], and negative feedback inhibit the excessive secretion of pituitary ACTH. Sexual differentiation of external genital organs was established during the seventh to twentieth week of pregnancy, fetal adrenal cortisol secretion in early pregnancy to prevent gender differentiation in androgen sensitive period of excessive androgen, high levels of cortisol inhibiting fetal HPA axis, remain in relatively low DHEA-S, particularly in females [25]. Subsequently, the expression of $33 \beta$-HSD2 is decreased, so is the secretion of cortisol, the inhibition of the HPA axis is also decreased, and the secretion of dhea-s is increased [26]. With the progress of the pregnancy, fetal paraventricular nucleus (paraventricular nucleus, PVN) strengthen the central drive of HPA axis, fetal adrenal cortex and HPA axis get rapid development [27] [28] [29] [30]. The late pregnancy HPA axis can respond to various physiological stresses in the uterus, and the reactivity of HPA axis to stress will increase continuously, therefore, fetal basal glucocorticoid level is gradually increased to promote the maturation of tissue morphology and function.

The early fetal adrenal cortex secretes a very small amount of salt corticosteroids, which increases during the last three months of gestation. In this period, the fetal blood of the human and rhesus monkey is $80 \%$ aldosterone from the fetal adrenal gland [31] [32]. At the 18th to 20th week of gestation, the metabolic pathways of corticosteroids in fetal adrenal glands are concentrated in the definitive zone, and their activity is very low [32].

\subsubsection{Rat}

Literature reported [17], the fetal rat adrenal gland growth and tissue development began at the 16th week of gestation, in this period, the expressions of P450scc, P450C11 and P450c21 were detected, as well as the secretion of cortisone [16] [33], it continued to increase from day 17 to day 18, followed by a significant decrease, and continued until the first day after birth, which was similar to previous reports [34] [35]. It is speculated that the decrease of corticosterone secretion after birth indicates the beginning of the stress non-responsive period (SNRP) [36]. This change is intended to stabilizethe body of glucocorticoid levels, ensure the normal development of neurons in brain regions sensitive to glucocorticoid. The expression of P450aldo and the secretion of aldosterone are detected in the 20th day of gestation [16] [33] and peaked at birth [34] [37]. 


\section{Regulatory Factors of Adrenal Development}

The adrenal gland develops autonomously 20 weeks ago. After 20 weeks, the fetal adrenal gland is regulated by the hypothalamus and pituitary gland, but the fetal adrenal gland does not have the circadian rhythm. Fetal adrenal gland development is mainly regulated by the pituitary anterior lobe adrenocortical hormone ACTH in addition to the growth factor (bFGF and EGF, IGF, and promote element, statin and TGF beta), intracellular receptor (SF-1, DAX-1), and the effect of placental hormone.

\subsection{The Fetal Pituitary and ACTH}

It is expected that the extraordinary growth and steroidogenic activity of the fetal adrenal cortex are dependent on an intact fetal pituitary gland as it produces $\mathrm{ACTH}$, the primary tropic regulator of the adrenal cortex. If there is absence of ACTH stimulation in anencephalic fetuses, the adrenal cortical development is obstructed. The experimental results showed that the fetal adrenal glands of the non-cerebral rhesus monkey were atrophied rapidly, and the maternal plasma estrogen decreased sharply [38] [39]. On the contrary, it can increase the concentration of fetal cortisol and maternal estrogen [38]. It can be seen that ACTH plays an important role in the growth and function of adrenal gland.

Although ACTH is the mainly regulation factor for fetal adrenal development, the early in gestation fetal zone growth and function are independent of ACTH. Before 10 - 15 weeks of gestation, adrenal development in anencephalic fetuses is normal, but thereafter the fetal zone fails to develop and does not exhibit characteristic growth and steroidogenic activity [40], indicating that early in gestation fetal zone growth and function are independent of ACTH. On the contrary, the definitive zone appears normal in anencephalic fetuses despite the absence of ACTH stimulation [41], suggesting that its growth is not dependent on ACTH at any stage in gestation, although its functional maturation appears to be regulated by ACTH [42]. In mid and late gestation, the reaction of fetal adrenal gland to ACTH is enhanced, which is caused by ACTH itself [43] [44] and other factors [45], especially the insulin-like growth factor I and II (insulin like growth factor I and II, IGFI and IGFII). ACTH is combined with the specific receptors on the surface of the adrenal cortex cells, the black leather receptor 2 (melanocortin receptor 2, MC2R) [46] [47], increases intracellular cAMP, also increases free cholesterol content and mitochondrial transport increases, thus promotes the synthesis of steroid hormones [48] [49].

\subsection{Growth Factor Regulation}

Research suggests that ACTH may not be a direct regulator of fetal adrenal glands. ACTH concentration in fetal circulation during middle and late gestation may be decreased, but the fetal band grows rapidly and produces a large amount of steroid hormones [50]. Although adrenal glands continue to be exposed to ACTH after birth, the fetal band atrophy and degenerate rapidly. 
Therefore, other factors, which may be unique to the intrauterine environment, play an important role in regulating the growth and development of the adrenal cortex.

\subsubsection{Insulin-Like Growth Factors I and II (IGF-I and IGF-II)}

IGF-I and IGF-II affect proliferation and differentiation in a wide variety of cell types and can act as autocrine, paracrine, or endocrine factors. There are two IGF receptors, designated type I and type II, have been identified. The type I receptor is structurally related to the insulin receptor and binds both IGF-I and IGF-II with high affinity and insulin with lower affinity. The type II receptor binds IGF-II with high affinity but will not bind IGF-I or insulin. Many fetal tissue express of IGF-I and IGF-II in the middle of the pregnancy, and the expression of IGF-II dominate in the womb [51] [52], fetal adrenal IGF-II expression is only after liver [53].

IGF-I and IGF-II can promote fetal adrenal cortical cell proliferation [53] through IGF-I receptor mediated [54]. IGF-I promote fetal sheep adrenal cortical cell proliferation, and by enhancing responsiveness of adrenal to ACTH and the activity of key enzymes of steroid hormones increase ACTH induced the synthesis of steroid hormones [55]. IGF-I can increase the expression of MC2R adrenal gland cells, promote the production of steroid hormone [56]. The mechanism may be related to the activation of the signaling pathways of adenosine/protein kinase A (PKA) and phospholipase C/protein kinase $\mathrm{C}$ (PKC) in the cell inner ring [57]. IGF-II also can affect the function of human fetal adrenal cortical cells differentiation [58], also reinforce induced fetus with ACTH cell secretion of cortisol and DHEA-S and steroid hormone synthetase P450scc, P450c17 and the expression of 3 beta HSD [45] [59].

\subsubsection{Epidermal Growth Factor (EGF)}

The fetal adrenal fetal band and the permanent cell surface express EGF receptor, which can promote the cultured cell division of the fetal adrenal fetal band and the definitive band in the mid trimester of pregnancy [60]. EGF treatment in vivo increased the amount of 3bHSD protein in definitive and transitional zone cells of fetal rhesus monkeys [61]. EGF can promote stimulate fetal sheep fetal adrenal gland secretion, secretion of pituitary ACTH and cortisol secretion of CRH hypothalamus [62], therefore, in addition to its potential direct effect on adrenal cortical cell proliferation, EGF also may modulate adrenal growth and functional maturation indirectly by affecting the hypothalamic-pituitary-adrenal axis.

\subsubsection{Basic Fibroblast Growth Factor (bFGF)}

BFGF can promote the proliferation of mesoderm and neuroectoderm cells, and has the function of promoting angiogenesis and neuronutrition. BFGF can promote the division of adrenal cortical cells in the Y-1 mouse [63]. BFGF can promote the proliferation of fetal adrenal zone and permanent zone, and the permanent zone is more sensitive to the mitogenic effect of bFGF [60]. At the 
same time, also to participate in rats after unilateral adrenal resection of compensatory growth of bilateral adrenal gland [64]. It has been shown that the increase of ACTH can be increased by 2 - 3 times with ACTH in the primary culture of human fetal adrenal cells [1]. Guasti, L. research that specific deletion of the Fgfr2 IIIb isoform impairs adrenal development, causing reduced adrenal growth and impaired expression of SF1 and steroidogenic enzymes [65]. Therefore, bFGF may be an important mediator of ACTH action in human fetal adrenal development.

\subsubsection{Transforming Growth Factor $\beta$ (TGF $\beta$ )}

$\mathrm{TGFb}$ is the prototypical peptide of a large family of growth factor proteins. Studies have shown that TGFb is involved in the regulation of fetal adrenal development, which may be related to the atrophy of the fetal band after birth, also may stimulate fetal cells differentiation for cortisol secretion [1], the effects on the fetus with specificity, inhibit the growth and the transformation of its birth. There are TGF beta-specific receptors in mammals, and TGF beta has a significant effect on the function of steroidal secretory cells. TGF beta binds to a specific site regulated by ACTH of human fetal adrenal cortex cells [66], inhibiting the proliferation of human adrenal fetuses and perinatal cells [67], basis and ACTH and cortisol, DHEA induced by cAMP-S secretion, inhibit expression of P450c17 [68], However, it has no effect on the expression of ACTH receptor and P450scc [69]. Therefore, TGF beta may inhibit the proliferation of fetal adrenal gland and steroid hormone synthesis by interacting with the specific ACTH binding site of the cell surface.

\subsection{Transcription Factors}

There are six important transcription factors which play a key role in the function of the adrenal cortex development: steroid synthesis of transcription factor (steroidogenic factor 1, SF1), DAX-1 (dosage-sensitive sex reversal, adrenal hypoplasia congenita, X-linked-1, DAX1), CBP/P300 transcription contain glutamic acid/aspartic acid C-end structure domain 2 (CBP/P300-interacting transactivator with Glu/Asp-rich-terminal domain 2 C, CITED2), Pre-B-cell transcription factor (pre-B-cell transcription factor 1, PBX1), Wilms Tumor factors (Wilms Tumor 1, WT1) and GATA binding protein (GATA). Mutations in these transcription factors will lead to the development, growth and/or dysfunction of the adrenal cortex [70] [71] [72].

\subsubsection{SF-1}

SF-1 is also known as the nuclear receptor family of five and group A (nuclear receptor subfamily 5 , group A, member $1, \mathrm{NR} 5 \mathrm{~A} 1$ ), don't find the endogenous ligand in the cell nuclear receptor, is a solitary nuclear receptor, is the first found to adjust the cytochrome P450 steroid synthetase transcription factor [73]. Subsequently, it has been confirmed in other laboratories that sf- 1 regulates the expression of various steroid genes and the synthesis of steroid hormones in the 
hypothalamic-pituitary-steroid hormone synthesis organs [74] [75]. Sf-1 is expressed in early fetal adrenal development, both in the fetal zone and in the final differentiation zone [76]. Sf-1 knockout mice would die 12 hours after birth due to the absence of adrenal and gonadal glands [77]. Similar studies have shown that the human adrenal glands do not form without the expression of sf-1 [78].

Due to the lack of sf- 1 in adrenal gonads, apoptosis of urinary reproductive crest cells and abnormal adrenal development can be caused [79]. These studies suggest that sf- 1 regulates apoptosis and proliferation and affects the development of adrenal glands. Particularly to stress is that exist in SF-1 promoter regions increase fetal adrenal hadron (fetal adrenal enhancer, FAdE) sequence, can regulate the expression of SF-1 through to affect the growth of fetal adrenal gland, and the regulation of adult adrenal gland have obvious different [80].

The promoter of all steroid hormone synthase has the binding site of sf- 1 , which regulates the expression of these enzymes, thus promoting the synthesis of steroid hormones [81] [82]. SF-1 is interaction with other transcription factors exist, Val and Swain [71] has speculated, adrenal tissue development in SF-1 activation model: first of all, WT1 induces SF-1 expression in adrenal glands primordium, CITED2 collaborative participation, then after PBX1 role in SF, FadE-1 promoter element to further promote, in the end, through self-adjusting for SF-1 expression. More importantly, SF-1 can promote expression of DAX1, while DAX1 can inhibit the activity of SF-1 and regulate the activity of adrenal steroid hormone through the negative feedback regulation pathway [82] [83] POD-1 inhibits SF-1 expression in adrenal cells [84].

The mutations and regulation of SF-1 are associated with the human gonadal gland and abnormal adrenal gland. Male SF-1 heterozygous mutation will lead to adrenal hypoplasia, and male and female sex reversal, while females heterozygous mutations, will delay the adrenal glands to develop and mature, there is ovarian dysplasia occasionally [81] [82] [85] [86]. These studies suggest that there is a gender difference in the effects of SF-1 on adrenal glands. On the contrary, there are also studies suggesting that the overexpression of SF-1 also causes adrenal cortical carcinoma [87] [88].

\subsubsection{DAX-1}

Dax-1 is another transcription factor that plays an important role in the regulation of adrenal development. Mutations in the DAX-1 gene are responsible for $\mathrm{X}$-linked adrenal hypoplasia congenita [89] [90]. On day 10.5 of gestation in rodents, dax-1 was expressed in the urinary reproductive crest, followed by the adrenal gonadotropin, and finally in the fetal adrenal gland and ovary [91]. The dax-1 mRNA abundance in adrenal glands is significantly higher in fetuses than in adults [92], which may be more important for fetal adrenal development. Dax-1 deficiency leads to early differentiation of adrenal cortical progenitor cells, leading to progenitor cell failure and adrenal insufficiency [88].

The tissue distribution of DAX-1 expression is similar to that of SF-1 [77] [93], suggesting that these two transcription factors may be a co-regulation fac- 
tor of the development and function of steroid hormone secretion. It has been reported that Dax1 promoter has SF-1 binding site [94], and subsequently in vitro experiments have also confirmed that SF-1 can be combined in its promoter region and promoted expression in JEG-3 cells [95]. In addition, in vitro experiments show that DAX1 inhibited the activity of SF-1 by directly binding SF-1 or by recruiting cosuppressor factors [71] [96]. Gummow [83], which give excess sugar cortical hormone in vitro experiments, SF-1 and glucocorticoid receptor (glucocorticoid receptor, GR) combined with Dax1 promoter, activate Dax1, restrain activity of SF-1, reduce the generation of steroid hormones. At the same time, the ACTH stimulus is given to isolate the SF-1 and GR complex, so as to inhibit Dax1 transcriptation and increase the steroidal synthesis of steroidal synthesis by SF-1 promotion [83].

In the mouse model of Sf1 knockout, the expression of Dax1 is not reduced completely, and there may be other channel regulation [97]. In vitro experiments have confirmed that DAX1 can be combined with its own promoter region to predict that the gene has its own regulation [98]. Jordan et al. [99] find that Wnt 4 can increase the expression of Dax 1 in developing ovaries, and block Wnt 4 and Dax 1 to cause the female and male of the fetus to be reversed. It is also reported that WT1 activated Dax1 promoter activity, which played an important role in the process of gender identification [100].

\subsubsection{CITED2}

CITED2 is a co-transcriptional activator of the cAMP (cAMP response element binding protein, CREB), which is associated with the development of multiple tissues, including the heart, adrenal gland and nerve tissue [101] [102]. There are adrenal development defects in the Cited2-/-mouse [103]. Val [104] finds that in the study of Cited 2 in adrenocortical development, Cited2 is expressed in the epithelial cells of the urogenital crest in the 10th day of the mouse embryo and co-activated Sf1 with Wt1. Research has also confirmed that [71] the synergistic effect of Cited2 and Wt1 causes the fluctuation of Sf1 in the adrenal gland primordium, resulting in the development defect, and the development of adrenal gland is more sensitive to this fluctuation than the gonadal gland.

CITED2 is expressed in the fetal adrenal glands [105]. Studies have shown that sf- 1 can be combined in the CITED2 promoter region to promote expression [105]. However, there is no CITED2 mutation in patients with adrenal dysplasia or defect, but there is new gene polymorphism. There is also a link between CITED2 and endothelial chemokines [102]. Adrenal gland has a complex vasculature, Endothelial cell is very important to the migration of adrenal cortex cells [106], CITED2 can be adjusted by angiogenesis factor and bFGF [103], thus speculate that CITED2 plays an important role in contact with adrenal cortical cells and adrenal endothelial cells, its specific mechanism of action is unknown. Studies have shown that in AGP, the expression of CITED2 is necessary for proper proportional differentiation of the adrenal primitive area (AP or fetal area-FZ) [4] [104]. 


\subsubsection{PBX1}

PBX1 is a homologous structural protein that regulates adrenal development. $\mathrm{Pbx1}$ was expressed in epithelial cells of the urinary reproductive crest on the 13.5th day of gestation. Female mice with Pbxl knockout were unable to complete the complete differentiation of the urinary reproductive crest, which resulted in the loss of adrenal gland and subsequent renal dysplasia [107]. The Pbxl knockout causes the hair and adrenal gland and the adrenal gland to be abnormal, and the hypothesized that the cell proliferation slows more than the cell apoptosis. Lichtenauer et al. [108] confirm that Pbx1 in adrenal gland development plays an important role in the embryonic development, not only in adult adrenal function also play an important role in maintain, at the same time, also finds that can increase $\mathrm{Pbx} 1$ expression Sf1, both increase Mc2R expression. Some studies have reported [105] that SF-1 has a weak activation effect on the promoter of PBX1, but when SF-1 and DAX1 work together, it promotes enhanced transcription.

\subsubsection{WT1}

WT1 is a zinc finger protein, which plays an important role in the development of urinary reproductive crest and subsequent adrenal gland [14] [71] [109]. WT1 is the first transcriptional factor needed for adrenal development. It is expressed in the urinary reproductive crest in the 9th day of pregnancy in mice [71], which is combined with Cited 2 to stimulate the expression of Sf1 and promote adrenal development [104] [110] [111]. Therefore, it is speculated that human chorionic gonadotropin (HCG) acts as an adrenocortical corticotropin in the fetus and regulates the production of fetal adrenal DHEAS. However, it does not affect the production of fetal adrenal steroid hormone [41] when it is given to the brainless HCG.

\subsubsection{GATA Binding Protein (GATA) 4 and GATA6}

GATA binding protein (GATA) 4 and GATA6 transcription factors have long been implicated in adrenal development [112] and adult adrenal function [113] [114] [115] [116]. Sergei, G., et al. [72] determined that adrenal loss of GATA function is incompatible with adrenocortical development. Specifically, a combined loss of GATA4and GATA6 in the precursor cells results in the loss of SF1expression, decreased adrenocortical proliferation, and adrenal agenesis in both sexes. GATA6 serves as a principal driver of adrenocortical cell maintenance, whereas GATA4 protein acts in an ancillary role, carrying out basic regulatory functions to support the requisite number of steroidogenic cells to assure animal viability in the absence of GATA6.

\subsection{Placental Factors}

Rapid degeneration of the fetuses at birth after separation from the placenta suggests that certain substances produced by the placenta may play a role in the development and/or maintenance of the placenta. Human placenta produces a variety of hormones (such as HCG, CRH, estrogen, etc.) that may affect the 
growth and function of the fetal adrenal gland [3] [117].

\subsubsection{HCG}

The CG produced by the placenta is a specific hormone characteristic of primates. Human fetal HCG production peaks at the 10th week of pregnancy and then begins to decline. Lanman [118] first proposed that HCG can regulate the development of fetal adrenal glands. Studies have found that [119], babies born to give a week after HCG, urine excretion of DHEA increased significantly, its effects on the fetus zone to promote the synthesis of steroid hormone, and is more sensitive than the full term of HCG in preterm neonates. In vitro experiments also confirmed [120] [121] that the secretion of DHEA-S increased when HCG was given in fetal adrenal cell culture medium of primary culture. Although numerous studies have confirmed the role of HCG in fetal adrenal development in primates, the mechanism of its action is still unclear.

\subsubsection{Estrogen}

DHEA-S produced by the fetal and maternal adrenal glands provide precursor to the synthesis of placental oestrogen, and the oestrogen produced by the placenta can also promote the secretion of DHEA-S in fetal adrenal glands [122]. Estrogen increases the ACTH-induced DHEA-S secretion in the fetal adrenal cortex and inhibits the secretion of cortisol [59], which does not affect the expression of the enzyme P450scc, P450c17 or $3 \beta$-HSD of synthetic cortisol [123]. Estrogen, the adjustment is the opposite of DHEA-S as a result, in vivo and in vitro experiments [124] [125], estrogen inhibits mid pregnancy baboons adrenal DHEA-S produce, offer estrogen suppresses the generation of fetal adrenal DHEA-S is to maintain the physiological balance between estrogen during pregnancy.

Estrogen can affect the target organs by estrogen receptors (estrogen receptors, ERs). Hirst [123] and other studies have found that monkeys in the middle of a pregnancy, the fetus fetal adrenal don't express ERs, It is speculated that estrogen to the fetus with function is not through the regulation of ERs, and then take the enzyme activity of steroid hormones on the fetus than other gene transcription regulation.

\subsubsection{CRH and ACTH}

Placental tissue can produce CRH [126] and ACTH [127]. CRH produced placental trophoblastic cells can be induced fit trophoblast cells secrete ACTH [128] [129], but the placenta ACTH secretion to adjust the action of fetal adrenal cortical level is not very clear, because its role in fetal adrenal gland development is small. The CRH secreted by the placenta can enter the fetal body, increasing $\mathrm{CRH}$ content in the fetus, affecting the development of fetal adrenal gland through the pituitary-adrenal axis of the fetus [130] [131].

\section{Summary}

The development and function of fetal adrenal cortex in mammals are unique, and play an important role in regulating the metabolic homeostasis of electro- 
lytes and nutrients. The structure and function of the adrenal dysplasia will lead to the production of a variety of diseases, not only has its recent harm, but there is also a long-term adverse effect, so it is of very vital significance to know the structure of fetal adrenal gland development and discuss its function regulation. At present, great progress has been made in the study of functional regulation of adrenal cortex. Transgenic and gene knockout mice play an important role in the study of adrenal cortical development. The development and function of adrenal cortex are regulated by multiple hormones, genes and mechanisms. Although significant progress has been made, studies on its underlying mechanisms, such as the occurrence of significant epigenetic modification of transcription factors and changes in specific gene-specific gender differences, have been relatively superficial. Recently, the primate of placenta on fetal adrenal cortical development regulation provides us a new point of view, through the fetus-placental unit to expand our physical contact between the placenta and fetal adrenal gland, and provides a new research perspective and field for us to study the function of the adrenal gland development.

\section{Funding Sources}

This work was supported by Grants from Chinese Nature Science Foundation (NO.81501269), Nature Science Foundation of Hubei Province (NO. 2018CFB667), the Yangtze Fund for Youth Teams of Science and Technology Innovation (NO. 2016cqt04).

\section{Conflicts of Interest}

The authors declare no conflicts of interest regarding the publication of this paper.

\section{References}

[1] Mesiano, S. and Jaffe, R.B. (1997) Developmental and Functional Biology of the Primate Fetal Adrenal Cortex. Endocrine Reviews, 18, 378-403. https://doi.org/10.1210/edrv.18.3.0304

[2] O'Donnell, K., O'Connor, T.G. and Glover, V. (2009) Prenatal Stress and Neurodevelopment of the Child: Focus on the HPA Axis and Role of the Placenta. Developmental Neuroscience, 31, 285-292. https://doi.org/10.1159/000216539

[3] Ishimoto, H. and Jaffe, R.B. (2011) Development and Function of the Human Fetal Adrenal Cortex: A Key Component in the Feto-Placental Unit. Endocrine Reviews, 32, 317-355. https://doi.org/10.1210/er.2010-0001

[4] Penny, M.K., Finco, I. and Hammer, G.D. (2017) Cell Signaling Pathways in the Adrenal Cortex: Links to Stem/Progenitor Biology and Neoplasia. Molecular and Cellular Endocrinology, 445, 42-54. https://doi.org/10.1016/j.mce.2016.12.005

[5] Vinson, G.P. (2016) Functional Zonation of the Adult Mammalian Adrenal Cortex. Frontiers in Neuroscience, 10, 238. https://doi.org/10.3389/fnins.2016.00238

[6] Coulter, C.L. (2005) Fetal Adrenal Development: Insight Gained from Adrenal Tumors. Trends in Endocrinology \& Metabolism, 16, 235-242.

https://doi.org/10.1016/j.tem.2005.05.010 
[7] Kempna, P. and Fluck, C.E. (2008) Adrenal Gland Development and Defects. Best Practice \& Research: Clinical Endocrinology \& Metabolism, 22, 77-93. https://doi.org/10.1016/j.beem.2007.07.008

[8] Sucheston, M.E. and Cannon, M.S. (1968) Development of Zonular Patterns in the Human Adrenal Gland. Journal of Morphology, 126, 477-491. https://doi.org/10.1002/jmor.1051260408

[9] Buster, J.E. (1980) Fetal Adrenal Cortex. Clinical Obstetrics and Gynecology, 23, 803-824. https://doi.org/10.1097/00003081-198023030-00011

[10] McNutt, N.S. and Jones, A.L. (1970) Observations on the Ultrastructure of Cytodifferentiation in the Human Fetal Adrenal Cortex. Laboratory Investigation, 22, 513-527.

[11] Mesiano, S., Coulter, C.L. and Jaffe, R.B. (1993) Localization of Cytochrome P450 Cholesterol Side-Chain Cleavage, Cytochrome P450 17 Alpha-Hydroxylase/17, 20-Lyase, and 3 Beta-Hydroxysteroid Dehydrogenase Isomerase Steroidogenic Enzymes in Human and Rhesus Monkey Fetal Adrenal Glands: Reappraisal of Functional Zonation. The Journal of Clinical Endocrinology \& Metabolism, 77, 1184-1189. https://doi.org/10.1210/jc.77.5.1184

[12] Mazilu, J.K. and McCabe, E.R.B. (2011) Moving toward Personalized Cell-Based Interventions for Adrenal Cortical Disorders: Part 1 Adrenal Development and Function, and Roles of Transcription Factors and Signaling Proteins. Molecular Genetics and Metabolism, 104, 72-79. https://doi.org/10.1016/j.ymgme.2011.06.014

[13] Hafner, R., Bohnenpoll, T., Rudat, C., Schultheiss, T.M. and Kispert, A. (2015) Fgfr2 Is Required for the Expansion of the Early Adrenocortical Primordium. Molecular and Cellular Endocrinology, 413, 168-177. https://doi.org/10.1016/j.mce.2015.06.022

[14] Keegan, C.E. and Hammer, G.D. (2002) Recent Insights into Organogenesis of the Adrenal Cortex. Trends in Endocrinology \& Metabolism, 13, 200-208. https://doi.org/10.1016/S1043-2760(02)00602-1

[15] Schulte, D.M., Shapiro, I., Reincke, M. and Beuschlein, F. (2007) Expression and Spatio-Temporal Distribution of Differentiation and Proliferation Markers during Mouse Adrenal Development. Gene Expression Patterns, 7, 72-81. https://doi.org/10.1016/j.modgep.2006.05.009

[16] Mitani, F., Mukai, K., Miyamoto, H., Suematsu, M. and Ishimura, Y. (1999) Development of Functional Zonation in the Rat Adrenal Cortex. Endocrinology, 140, 3342-3353. https://doi.org/10.1210/endo.140.7.6859

[17] Roos, T.B. (1967) Steroid Synthesis in Embryonic and Fetal Rat Adrenal Tissue. Endocrinology, 81, 716-728. https://doi.org/10.1210/endo-81-4-716

[18] Mitani, F., Mukai, K., Miyamoto, H., Suematsu, M. and Ishimura, Y. (2003) The Undifferentiated Cell Zone Is a Stem Cell Zone in Adult Rat Adrenal Cortex. Biochimica et Biophysica Acta, 1619, 317-324. https://doi.org/10.1016/S0304-4165(02)00490-7

[19] Mitani, F. (2014) Functional Zonation of the Rat Adrenal Cortex: The Development and Maintenance. Proceedings of the Japan Academy, Ser. B, Physical and Biological Sciences, 90, 163-183. https://doi.org/10.2183/pjab.90.163

[20] Payne, A.H. and Hales, D.B. (2004) Overview of Steroidogenic Enzymes in the Pathway from Cholesterol to Active Steroid Hormones. Endocrine Reviews, 25, 947-970. https://doi.org/10.1210/er.2003-0030

[21] Mizutani, T., Ishikane, S., Kawabe, S., Umezawa, A. and Miyamoto, K. (2015) Transcriptional Regulation of Genes Related to Progesterone Production. Endo- 
crine Journal, 62, 757-763. https://doi.org/10.1507/endocrj.EJ15-0260

[22] Pezzi, V., Mathis, J.M., Rainey, W.E. and Carr, B.R. (2003) Profiling Transcript Levels for Steroidogenic Enzymes in Fetal Tissues. The Journal of Steroid Biochemistry and Molecular Biology, 87, 181-189. https://doi.org/10.1016/j.jsbmb.2003.07.006

[23] Melau, C., Nielsen, J.E., Frederiksen, H., Kilcoyne, K., Perlman, S., Lundvall, L., et al. (2019) Characterization of Human Adrenal Steroidogenesis during Fetal Development. The Journal of Clinical Endocrinology \& Metabolism, 104, 1802-1812. https://doi.org/10.1210/jc.2018-01759

[24] Goto, M., Brickwood, S., Wilson, D.I., Wood, P.J., Mason, J.I. and Hanley, N.A. (2002) Steroidogenic Enzyme Expression within the Adrenal Cortex during Early Human Gestation. Endocrine Research, 28, 641-645. https://doi.org/10.1081/ERC-120016979

[25] Goto, M., Piper Hanley, K., Marcos, J., Wood, P.J., Wright, S., Postle, A.D., et al. (2006) In Humans, Early Cortisol Biosynthesis Provides a Mechanism to Safeguard Female Sexual Development. Journal of Clinical Investigation, 116, 953-960. https://doi.org/10.1172/JCI25091

[26] White, P.C. (2006) Ontogeny of Adrenal Steroid Biosynthesis: Why Girls Will Be Girls. Journal of Clinical Investigation, 116, 872-874. https://doi.org/10.1172/JCI28296

[27] Lingas, R., Dean, F. and Matthews, S.G. (1999) Maternal Nutrient Restriction (48 h) Modifies Brain Corticosteroid Receptor Expression and Endocrine Function in the Fetal Guinea Pig. Brain Research, 846, 236-242. https://doi.org/10.1016/S0006-8993(99)02058-2

[28] Takahashi, L.K., Turner, J.G. and Kalin, N.H. (1998) Prolonged Stress-Induced Elevation in Plasma Corticosterone during Pregnancy in the Rat: Implications for Prenatal Stress Studies. Psychoneuroendocrinology, 23, 571-581. https://doi.org/10.1016/S0306-4530(98)00024-9

[29] Koehl, M., Darnaudery, M., Dulluc, J., Van Reeth, O., Le Moal, M. and Maccari, S. (1999) Prenatal Stress Alters Circadian Activity of Hypothalamo-Pituitary-Adrenal Axis and Hippocampal Corticosteroid Receptors in Adult Rats of Both Gender. Journal of Neurobiology, 40, 302-315. https://doi.org/10.1002/(SICI)1097-4695(19990905)40:3<302::AID-NEU3>3.0.CO;2 $-7$

[30] McTernan, C.L., Draper, N., Nicholson, H., Chalder, S.M., Driver, P., Hewison, M., et al. (2001) Reduced Placental 11beta-hydroxysteroid Dehydrogenase Type 2 mRNA Levels in Human Pregnancies Complicated by Intrauterine Growth Restriction: An Analysis of Possible Mechanisms. The Journal of Clinical Endocrinology \& Metabolism, 86, 4979-4983. https://doi.org/10.1210/jcem.86.10.7893

[31] Bayard, F., Ances, I.G., Tapper, A.J., Weldon, V.V., Kowarski, A. and Migeon, C.J. (1970) Transplacental Passage and Fetal Secretion of Aldosterone. Journal of Clinical Investigation, 49, 1389-1393. https://doi.org/10.1172/JCI106356

[32] Seron-Ferre, M., Biglieri, E.G. and Jaffe, R.B. (1990) Regulation of Mineralocorticoid Secretion by the Superfused Fetal Monkey Adrenal Gland: Lack of Stimulation of Aldosterone by ACTH. Journal of Developmental Physiology, 13, 33-36.

[33] Wotus, C., Levay-Young, B.K., Rogers, L.M., Gomez-Sanchez, C.E. and Engeland, W.C. (1998) Development of Adrenal Zonation in Fetal Rats Defined by Expression of Aldosterone Synthase and 11beta-hydroxylase. Endocrinology, 139, 4397-4403. 
https://doi.org/10.1210/endo.139.10.6230

[34] Dalle, M., Giry, J., Gay, M. and Delost, P. (1978) Perinatal Changes in Plasma and Adrenal Corticosterone and Aldosterone Concentrations in the Mouse. Journal of Endocrinology, 76, 303-309. https://doi.org/10.1677/joe.0.0760303

[35] Dupouy, J.P., Coffigny, H. and Magre, S. (1975) Maternal and Foetal Corticosterone Levels during Late Pregnancy in Rats. Journal of Endocrinology, 65, 347-352. https://doi.org/10.1677/joe.0.0650347

[36] Sapolsky, R.M. and Meaney, M.J. (1986) Maturation of the Adrenocortical Stress Response: Neuroendocrine Control Mechanisms and the Stress Hyporesponsive Period. Brain Research, 396, 64-76. https://doi.org/10.1016/0165-0173(86)90010-X

[37] Bondarenko, N.S., Murtazina, A.R., Nikishina, Y.O., Sapronova, A.Y. and Ugrumov, M.V. (2017) Molecular Mechanisms of Synthesis of Noradrenaline as an Inducer of Development in the Adrenal Glands of Rats in Ontogenesis. Doklady Biochemistry and Biophysics, 472, 23-26. https://doi.org/10.1134/S1607672917010070

[38] Walsh, S.W., Norman, R.L. and Novy, M.J. (1979) In Utero Regulation of Rhesus Monkey Fetal Adrenals: Effects of Dexamethasone, Adrenocorticotropin, Thyrotropin-Releasing Hormone, Prolactin, Human Chorionic Gonadotropin, and Alpha-Melanocyte-Stimulating Hormone on Fetal and Maternal Plasma Steroids. Endocrinology, 104, 1805-1813. https://doi.org/10.1210/endo-104-6-1805

[39] Novy, M.J., Walsh, S.W. and Kittinger, G.W. (1977) Experimental Fetal Anencephaly in the Rhesus Monkey: Effect on Gestational Length and Fetal and Maternal Plasma Steroids. The Journal of Clinical Endocrinology \& Metabolism, 45, 1031-1038. https://doi.org/10.1210/jcem-45-5-1031

[40] Gray, E.S. and Abramovich, D.R. (1980) Morphologic Features of the Anencephalic Adrenal Gland in Early Pregnancy. American Journal of Obstetrics \& Gynecology, 137, 491-495. https://doi.org/10.1016/0002-9378(80)91134-5

[41] Honnebier, W.J., Jobsis, A.C. and Swaab, D.F. (1974) The Effect of Hypophysial Hormones and Human Chorionic Gonadotrophin (HCG) on the Anencephalic Fetal Adrenal Cortex and on Parturition in the Human. The Journal of Obstetrics and Gynaecology of the British Commonwealth, 81, 423-438. https://doi.org/10.1111/j.1471-0528.1974.tb00492.x

[42] Coulter, C.L., Goldsmith, P.C., Mesiano, S., Voytek, C.C., Martin, M.C., Mason, J.I., et al. (1996) Functional Maturation of the Primate Fetal Adrenal in Vivo. II. Ontogeny of Corticosteroid Synthesis Is Dependent upon Specific Zonal Expression of 3 Beta-Hydroxysteroid Dehydrogenase/Isomerase. Endocrinology, 137, 4953-4959. https://doi.org/10.1210/endo.137.11.8895368

[43] Di Blasio, A.M. and Jaffe, R.B. (1988) Adrenocorticotropic Hormone Does Not Induce Desensitization in Human Adrenal Cells during Fetal Life. Biology of Reproduction, 39, 617-621. https://doi.org/10.1095/biolreprod39.3.617

[44] Mesiano, S., Fujimoto, V.Y., Nelson, L.R., Lee, J.Y., Voytek, C.C. and Jaffe, R.B. (1996) Localization and Regulation of Corticotropin Receptor Expression in the Midgestation Human Fetal Adrenal Cortex: Implications for in Utero Homeostasis. The Journal of Clinical Endocrinology \& Metabolism, 81, 340-345. https://doi.org/10.1210/jcem.81.1.8550775

[45] Mesiano, S., Katz, S.L., Lee, J.Y. and Jaffe, R.B. (1997) Insulin-Like Growth Factors Augment Steroid Production and Expression of Steroidogenic Enzymes in Human Fetal Adrenal Cortical Cells: Implications for Adrenal Androgen Regulation. The Journal of Clinical Endocrinology \& Metabolism, 82, 1390-1396. https://doi.org/10.1210/jc.82.5.1390 
[46] Mountjoy, K.G., Robbins, L.S., Mortrud, M.T. and Cone, R.D. (1992) The Cloning of a Family of Genes That Encode the Melanocortin Receptors. Science, 257, 1248-1251. https://doi.org/10.1126/science.1325670

[47] Novoselova, T., King, P., Guasti, L., Metherell, L.A., Clark, A.J.L. and Chan, L.F. (2019) ACTH Signalling and Adrenal Development: Lessons from Mouse Models. Endocrine Connections, 8, pii: EC-19-0190.R1.

[48] Ulrich-Lai, Y.M., Arnhold, M.M. and Engeland, W.C. (2006) Adrenal Splanchnic Innervation Contributes to the Diurnal Rhythm of Plasma Corticosterone in Rats by Modulating Adrenal Sensitivity to ACTH. The American Journal of Physiology-Regulatory, Integrative and Comparative, 290, R1128-R1135. https://doi.org/10.1152/ajpregu.00042.2003

[49] Babischkin, J.S., Aberdeen, G.W., Pepe, G.J. and Albrecht, E.D. (2016) Estrogen Suppresses Interaction of Melanocortin 2 Receptor and Its Accessory Protein in the Primate Fetal Adrenal Cortex. Endocrinology, 157, 4588-45601. https://doi.org/10.1210/en.2016-1562

[50] Winters, A.J., Oliver, C., Colston, C., MacDonald, P.C. and Porter, J.C. (1974) Plasma ACTH Levels in the Human Fetus and Neonate as Related to Age and Parturition. The Journal of Clinical Endocrinology \& Metabolism, 39, 269-273. https://doi.org/10.1210/jcem-39-2-269

[51] Ilvesmaki, V., Blum, W.F. and Voutilainen, R. (1993) Insulin-Like Growth Factor Binding Proteins in the Human Adrenal Gland. Molecular and Cellular Endocrinology, 97, 71-79. https://doi.org/10.1016/0303-7207(93)90212-3

[52] Guasti, L., Candy Sze, W.C., McKay, T., Grose, R. and King, P.J. (2013) FGF Signalling through Fgfr2 Isoform IIIb Regulates Adrenal Cortex Development. Molecular and Cellular Endocrinology, 371, 182-188. https://doi.org/10.1016/j.mce.2013.01.014

[53] Han, V.K., Lund, P.K., Lee, D.C. and D’Ercole, A.J. (1988) Expression of Somatomedin/Insulin-Like Growth Factor Messenger Ribonucleic Acids in the Human Fetus: Identification, Characterization, and Tissue Distribution. The Journal of Clinical Endocrinology \& Metabolism, 66, 422-429. https://doi.org/10.1210/jcem-66-2-422

[54] Osborne, C.K., Coronado, E.B., Kitten, L.J., Arteaga, C.I., Fuqua, S.A., Ramasharma, K., et al. (1989) Insulin-Like Growth Factor-II (IGF-II), a Potential Autocrine/Paracrine Growth Factor for Human Breast Cancer Acting via the IGF-I Receptor. Molecular Endocrinology, 3, 1701-1709.

https://doi.org/10.1210/mend-3-11-1701

[55] van Wijk, P.A., Rijnberk, A., Croughs, R.J., Meij, B.P. and Mol, J.A. (1998) Effects of Corticotrophin-Releasing Hormone, Vasopressin and Insulin-Like Growth Factor-I on Proliferation of and Adrenocorticotrophic Hormone Secretion by Canine Corticotrophic Adenoma Cells in Vitro. European Journal of Endocrinology, 138, 309-315. https://doi.org/10.1530/eje.0.1380309

[56] Le Roy, C., Li, J.Y., Stocco, D.M., Langlois, D. and Saez, J.M. (2000) Regulation by Adrenocorticotropin (ACTH), Angiotensin II, Transforming Growth Factor-Beta, and Insulin-Like Growth Factor I of Bovine Adrenal Cell Steroidogenic Capacity and Expression of ACTH Receptor, Steroidogenic Acute Regulatory Protein, Cytochrome P450c17, and 3beta-Hydroxysteroid Dehydrogenase. Endocrinology, 141, 1599-1607. https://doi.org/10.1210/endo.141.5.7457

[57] Raha, D., Nehar, S., Paswan, B., Rebuffat, P., Neri, G., Naskar, R., et al. (2007) IGF-I Enhances Cortisol Secretion from Guinea-Pig Adrenal Gland: In Vivo and in Vitro Study. International Journal of Molecular Medicine, 20, 91-95. 
[58] Angelousi, A., Kyriakopoulos, G., Nasiri-Ansari, N., Karageorgou, M. and Kassi, E. (2018) The Role of Epithelial Growth Factors and Insulin Growth Factors in the Adrenal Neoplasms. Annals of Translational Medicine, 6, 253. https://doi.org/10.21037/atm.2018.05.52

[59] Mesiano, S. and Jaffe, R.B. (1993) Interaction of Insulin-Like Growth Factor-II and Estradiol Directs Steroidogenesis in the Human Fetal Adrenal toward Dehydroepiandrosterone Sulfate Production. The Journal of Clinical Endocrinology \& Metabolism, 77, 754-758. https://doi.org/10.1210/jc.77.3.754

[60] Hornsby, P.J., Sturek, M., Harris, S.E. and Simonian, M.H. (1983) Serum and Growth Factor Requirements for Proliferation of Human Adrenocortical Cells in Culture: Comparison with Bovine Adrenocortical Cells. In Vitro, 19, 863-869. https://doi.org/10.1007/BF02618166

[61] Coulter, C.L., Read, L.C., Carr, B.R., Tarantal, A.F., Barry, S. and Styne, D.M. (1996) A Role for Epidermal Growth Factor in the Morphological and Functional Maturation of the Adrenal Gland in the Fetal Rhesus Monkey in Vivo. The Journal of Clinical Endocrinology \& Metabolism, 81, 1254-1260.

https://doi.org/10.1210/jcem.81.3.8772608

[62] Luger, A., Calogero, A.E., Kalogeras, K., Gallucci, W.T., Gold, P.W., Loriaux, D.L., et al. (1988) Interaction of Epidermal Growth Factor with the Hypothalamic-Pituitary-Adrenal Axis: Potential Physiologic Relevance. The Journal of Clinical Endocrinology \& Metabolism, 66, 334-337.

https://doi.org/10.1210/jcem-66-2-334

[63] Gospodarowicz, D. and Handley, H.H. (1975) Stimulation of Division of Y1 Adrenal Cells by a Growth Factor Isolated from Bovine Pituitary Glands. Endocrinology, 97, 102-107. https://doi.org/10.1210/endo-97-1-102

[64] Basile, D.P. and Holzwarth, M.A. (1994) Basic Fibroblast Growth Factor Receptor in the Rat Adrenal Cortex: Effects of Suramin and Unilateral Adrenalectomy on Receptor Numbers. Endocrinology, 134, 2482-2489.

https://doi.org/10.1210/endo.134.6.8194474

[65] Zhou, J., Shaikh, L.H., Neogi, S.G., McFarlane, I., Zhao, W., Figg, N., et al. (2015) DACH1, a Zona Glomerulosa Selective Gene in the Human Adrenal, Activates Transforming Growth Factor-Beta Signaling and Suppresses Aldosterone Secretion. Hypertension, 65, 1103-1110. https://doi.org/10.1161/HYP.0000000000000025

[66] Stankovic, A.K. and Parker, C.R. (1995) Receptor Binding of Transforming Growth Factor-Beta by Human Fetal Adrenal Cells. Molecular and Cellular Endocrinology, 109, 159-165. https://doi.org/10.1016/0303-7207(95)03498-V

[67] Parker, C.R., Stankovic, A.K., Harlin, C. and Carden, L. (1992) Adrenocorticotropin Interferes with Transforming Growth Factor-Beta-Induced Growth Inhibition of Neocortical Cells from the Human Fetal Adrenal Gland. The Journal of Clinical Endocrinology \& Metabolism, 75, 1519-1521. https://doi.org/10.1210/jc.75.6.1519

[68] Stankovic, A.K., Dion, L.D. and Parker, C.R. (1994) Effects of Transforming Growth Factor-Beta on Human Fetal Adrenal Steroid Production. Molecular and Cellular Endocrinology, 99, 145-151. https://doi.org/10.1016/0303-7207(94)90002-7

[69] Lebrethon, M.C., Jaillard, C., Naville, D., Begeot, M. and Saez, J.M. (1994) Regulation of Corticotropin and Steroidogenic Enzyme mRNAs in Human Fetal Adrenal Cells by Corticotropin, Angiotensin-II and Transforming Growth Factor Beta 1. Molecular and Cellular Endocrinology, 106, 137-143. https://doi.org/10.1016/0303-7207(94)90195-3

[70] Hammer, G.D., Parker, K.L. and Schimmer, B.P. (2005) Mini-Review: Transcrip- 
tional Regulation of Adrenocortical Development. Endocrinology, 146, 1018-1024. https://doi.org/10.1210/en.2004-1385

[71] Val, P. and Swain, A. (2010) Gene Dosage Effects and Transcriptional Regulation of Early Mammalian Adrenal Cortex Development. Molecular and Cellular Endocrinology, 323, 105-114. https://doi.org/10.1016/j.mce.2009.12.010

[72] Tevosian, S.G., Jimenez, E., Hatch, H.M., Jiang, T., Morse, D.A., Fox, S.C., et al. (2015) Adrenal Development in Mice Requires GATA4 and GATA6 Transcription Factors. Endocrinology, 156, 2503-2517. https://doi.org/10.1210/en.2014-1815

[73] Luo, X., Ikeda, Y., Lala, D., Rice, D., Wong, M. and Parker, K.L. (1999) Steroidogenic Factor 1 (SF-1) Is Essential for Endocrine Development and Function. The Journal of Steroid Biochemistry and Molecular Biology, 69, 13-18. https://doi.org/10.1016/S0960-0760(98)00146-0

[74] Parker, K.L., Rice, D.A., Lala, D.S., Ikeda, Y., Luo, X., Wong, M., et al. (2002) Steroidogenic Factor 1: An Essential Mediator of Endocrine Development. Recent Progress in Hormone Research, 57, 19-36. https://doi.org/10.1210/rp.57.1.19

[75] Morohashi, K. (1999) Gonadal and Extragonadal Functions of Ad4BP/SF-1: Developmental Aspects. Trends in Endocrinology \& Metabolism, 10, 169-173. https://doi.org/10.1016/S1043-2760(98)00142-8

[76] Hanley, N.A., Rainey, W.E., Wilson, D.I., Ball, S.G. and Parker, K.L. (2001) Expression Profiles of SF-1, DAX1, and CYP17 in the Human Fetal Adrenal Gland: Potential Interactions in Gene Regulation. Molecular Endocrinology, 15, 57-68. https://doi.org/10.1210/mend.15.1.0585

[77] Luo, X., Ikeda, Y. and Parker, K.L. (1994) A Cell-Specific Nuclear Receptor Is Essential for Adrenal and Gonadal Development and Sexual Differentiation. Cell, 77, 481-490. https://doi.org/10.1016/0092-8674(94)90211-9

[78] El-Khairi, R., Martinez-Aguayo, A., Ferraz-de-Souza, B., Lin, L. and Achermann, J.C. (2011) Role of DAX-1 (NR0B1) and Steroidogenic Factor-1 (NR5A1) in Human Adrenal Function. Endocrine Development, 20, 38-46. https://doi.org/10.1159/000321213

[79] Sadovsky, Y., Crawford, P.A., Woodson, K.G., Polish, J.A., Clements, M.A., Tourtellotte, L.M., et al. (1995) Mice Deficient in the Orphan Receptor Steroidogenic Factor 1 Lack Adrenal Glands and Gonads But Express P450 Side-Chain-Cleavage Enzyme in the Placenta and Have Normal Embryonic Serum Levels of Corticosteroids. Proceedings of the National Academy of Sciences of the United States of America, 92, 10939-10943. https://doi.org/10.1073/pnas.92.24.10939

[80] Zubair, M., Ishihara, S., Oka, S., Okumura, K. and Morohashi, K. (2006) Two-Step Regulation of Ad4BP/SF-1 Gene Transcription during Fetal Adrenal Development: Initiation by a Hox-Pbx1-Prep1 Complex and Maintenance via Autoregulation by Ad4BP/SF-1. Molecular and Cellular Biology, 26, 4111-4121. https://doi.org/10.1128/MCB.00222-06

[81] Schimmer, B.P. and White, P.C. (2010) Minireview: Steroidogenic Factor 1: Its Roles in Differentiation, Development, and Disease. Molecular Endocrinology, 24, 1322-1337. https://doi.org/10.1210/me.2009-0519

[82] Hoivik, E.A., Lewis, A.E., Aumo, L. and Bakke, M. (2010) Molecular Aspects of Steroidogenic Factor 1 (SF-1). Molecular and Cellular Endocrinology, 315, 27-39. https://doi.org/10.1016/j.mce.2009.07.003

[83] Gummow, B.M., Scheys, J.O., Cancelli, V.R. and Hammer, G.D. (2006) Reciprocal Regulation of a Glucocorticoid Receptor-Steroidogenic Factor-1 Transcription 
Complex on the Dax-1 Promoter by Glucocorticoids and Adrenocorticotropic Hormone in the Adrenal Cortex. Molecular Endocrinology, 20, 2711-2723. https://doi.org/10.1210/me.2005-0461

[84] Franca, M.M., Abreu, N.P., Vrechi, T.A. and Lotfi, C.F. (2015) POD-1/Tcf21 Overexpression Reduces Endogenous SF-1 and StAR Expression in Rat Adrenal Cells. Brazilian Journal of Medical and Biological Research, 48, 1087-1094. https://doi.org/10.1590/1414-431x20154748

[85] Phelan, J.K. and McCabe, E.R. (2001) Mutations in NR0B1 (DAX1) and NR5A1 (SF1) Responsible for Adrenal Hypoplasia Congenita. Human Mutation, 18, 472-487. https://doi.org/10.1002/humu.1225

[86] Lin, L., Gu, W.X., Ozisik, G., To, W.S., Owen, C.J., Jameson, J.L., et al. (2006) Analysis of DAX1 (NR0B1) and Steroidogenic Factor-1 (NR5A1) in Children and Adults with Primary Adrenal Failure: Ten Years' Experience. The Journal of Clinical Endocrinology \& Metabolism, 91, 3048-3054. https://doi.org/10.1210/jc.2006-0603

[87] Pianovski, M.A., Cavalli, L.R., Figueiredo, B.C., Santos, S.C., Doghman, M., Ribeiro, R.C., et al. (2006) SF-1 Overexpression in Childhood Adrenocortical Tumours. European Journal of Cancer, 42, 1040-1043. https://doi.org/10.1016/j.ejca.2006.01.022

[88] Walczak, E.M. and Hammer, G.D. (2015) Regulation of the Adrenocortical Stem Cell Niche: Implications for Disease. Nature Reviews Endocrinology, 11, 14-28. https://doi.org/10.1038/nrendo.2014.166

[89] Muscatelli, F., Strom, T.M., Walker, A.P., Zanaria, E., Recan, D., Meindl, A., et al. (1994) Mutations in the DAX-1 Gene Give Rise to Both X-Linked Adrenal Hypoplasia Congenita and Hypogonadotropic Hypogonadism. Nature, 372, 672-676. https://doi.org/10.1038/372672a0

[90] Reutens, A.T., Achermann, J.C., Ito, M., Gu, W.X., Habiby, R.L., Donohoue, P.A., et al. (1999) Clinical and Functional Effects of Mutations in the DAX-1 Gene in Patients with Adrenal Hypoplasia Congenita. The Journal of Clinical Endocrinology \& Metabolism, 84, 504-511. https://doi.org/10.1210/jcem.84.2.5468

[91] Achermann, J.C., Meeks, J.J. and Jameson, J.L. (2001) Phenotypic Spectrum of Mutations in DAX-1 and SF-1. Molecular and Cellular Endocrinology, 185, 17-25. https://doi.org/10.1016/S0303-7207(01)00619-0

[92] Zanaria, E., Muscatelli, F., Bardoni, B., Strom, T.M., Guioli, S., Guo, W., et al. (1994) An Unusual Member of the Nuclear Hormone Receptor Superfamily Responsible for X-Linked Adrenal Hypoplasia Congenita. Nature, 372, 635-641. https://doi.org/10.1038/372635a0

[93] Ikeda, Y., Shen, W.H., Ingraham, H.A. and Parker, K.L. (1994) Developmental Expression of Mouse Steroidogenic Factor-1, an Essential Regulator of the Steroid Hydroxylases. Molecular Endocrinology, 8, 654-662.

https://doi.org/10.1210/mend.8.5.8058073

[94] Guo, W., Burris, T.P., Zhang, Y.H., Huang, B.L., Mason, J., Copeland, K.C., et al. (1996) Genomic Sequence of the DAX1 Gene: An Orphan Nuclear Receptor Responsible for X-Linked Adrenal Hypoplasia Congenita and Hypogonadotropic Hypogonadism. The Journal of Clinical Endocrinology \& Metabolism, 81, 2481-2486. https://doi.org/10.1210/jc.81.7.2481

[95] Yu, R.N., Ito, M. and Jameson, J.L. (1998) The Murine Dax-1 Promoter Is Stimulated by SF-1 (Steroidogenic Factor-1) and Inhibited by COUP-TF (Chicken Ovalbumin Upstream Promoter-Transcription Factor) via a Composite Nuclear Recep- 
tor-Regulatory Element. Molecular Endocrinology, 12, 1010-1022.

https://doi.org/10.1210/mend.12.7.0131

[96] Ito, M., Yu, R. and Jameson, J.L. (1997) DAX-1 Inhibits SF-1-Mediated Transactivation via a Carboxy-Terminal Domain That Is Deleted in Adrenal Hypoplasia Congenita. Molecular and Cellular Biology, 17, 1476-1483.

https://doi.org/10.1128/MCB.17.3.1476

[97] Ikeda, Y., Swain, A., Weber, T.J., Hentges, K.E., Zanaria, E., Lalli, E., et al. (1996) Steroidogenic Factor 1 and Dax-1 Colocalize in Multiple Cell Lineages: Potential Links in Endocrine Development. Molecular Endocrinology, 10, 1261-1272. https://doi.org/10.1210/mend.10.10.9121493

[98] Zazopoulos, E., Lalli, E., Stocco, D.M. and Sassone-Corsi, P. (1997) DNA Binding and Transcriptional Repression by DAX-1 Blocks Steroidogenesis. Nature, 390, 311-315. https://doi.org/10.1038/36899

[99] Jordan, B.K., Mohammed, M., Ching, S.T., Delot, E., Chen, X.N., Dewing, P., et al. (2001) Up-Regulation of WNT-4 Signaling and Dosage-Sensitive Sex Reversal in Humans. American Journal of Human Genetics, 68, 1102-1109.

https://doi.org/10.1086/320125

[100] Kim, J., Prawitt, D., Bardeesy, N., Torban, E., Vicaner, C., Goodyer, P., et al. (1999) The Wilms' Tumor Suppressor Gene (wt1) Product Regulates Dax-1 Gene Expression during Gonadal Differentiation. Molecular and Cellular Biology, 19, 2289-2299. https://doi.org/10.1128/MCB.19.3.2289

[101] Bamforth, S.D., Braganca, J., Eloranta, J.J., Murdoch, J.N., Marques, F.I., Kranc, K.R., et al. (2001) Cardiac Malformations, Adrenal Agenesis, Neural Crest Defects and Exencephaly in Mice Lacking Cited2, a New Tfap2 Co-Activator. Nature Genetics, 29, 469-474. https://doi.org/10.1038/ng768

[102] Haase, M., Ansurudeen, I., Schinner, S., Paramonova, I., Schott, M., Papewalis, C., et al. (2009) Evidence for the Involvement of Endothelial Cell Products in Adrenal CITED2 Expression. Cell and Tissue Research, 336, 337-343. https://doi.org/10.1007/s00441-009-0771-4

[103] Haase, M., Schott, M., Bornstein, S.R., Malendowicz, L.K., Scherbaum, W.A. and Willenberg, H.S. (2007) CITED2 Is Expressed in Human Adrenocortical Cells and Regulated by Basic Fibroblast Growth Factor. Journal of Endocrinology, 192, 459-465. https://doi.org/10.1677/JOE-06-0083

[104] Val, P., Martinez-Barbera, J.P. and Swain, A. (2007) Adrenal Development Is Initiated by Cited 2 and Wt1 through Modulation of Sf-1 Dosage. Development, 134, 2349-2358. https://doi.org/10.1242/dev.004390

[105] Ferraz-de-Souza, B., Martin, F., Mallet, D., Hudson-Davies, R.E., Cogram, P., Lin, L., et al. (2009) CBP/p300-Interacting Transactivator, with Glu/Asp-Rich C-Terminal Domain, 2, and Pre-B-Cell Leukemia Transcription Factor 1 in Human Adrenal Development and Disease. The Journal of Clinical Endocrinology \& Metabolism, 94, 678-683. https://doi.org/10.1210/jc.2008-1064

[106] Liu, Y.W. and Guo, L. (2006) Endothelium Is Required for the Promotion of Interrenal Morphogenetic Movement during Early Zebrafish Development. Developmental Biology, 297, 44-58. https://doi.org/10.1016/j.ydbio.2006.04.464

[107] Schnabel, C.A., Selleri, L. and Cleary, M.L. (2003) Pbx1 Is Essential for Adrenal Development and Urogenital Differentiation. Genesis, 37, 123-130. https://doi.org/10.1002/gene.10235

[108] Lichtenauer, U.D., Duchniewicz, M., Kolanczyk, M., Hoeflich, A., Hahner, S., Else, T., et al. (2007) Pre-B-Cell Transcription Factor 1 and Steroidogenic Factor 1 Syn- 
ergistically Regulate Adrenocortical Growth and Steroidogenesis. Endocrinology, 148, 693-704. https://doi.org/10.1210/en.2006-0681

[109] Klattig, J., Sierig, R., Kruspe, D., Makki, M.S. and Englert, C. (2007) WT1-Mediated Gene Regulation in Early Urogenital Ridge Development. Sexual Development, 1, 238-254. https://doi.org/10.1159/000104774

[110] Ambu, R., Vinci, L., Gerosa, C., Fanni, D., Obinu, E., Faa, A., et al. (2015) WT1 Expression in the Human Fetus during Development. European Journal of Histochemistry, 59, 2499. https://doi.org/10.4081/ejh.2015.2499

[111] Bandiera, R., Vidal, V.P., Motamedi, F.J., Clarkson, M., Sahut-Barnola, I., von Gise, A., et al. (2013) WT1 Maintains Adrenal-Gonadal Primordium Identity and Marks a Population of AGP-Like Progenitors within the Adrenal Gland. Developmental Cell, 27, 5-18. https://doi.org/10.1016/j.devcel.2013.09.003

[112] Kiiveri, S., Liu, J., Westerholm-Ormio, M., Narita, N., Wilson, D.B., Voutilainen, R., et al. (2002) Transcription Factors GATA-4 and GATA-6 during Mouse and Human Adrenocortical Development. Endocrine Research, 28, 647-650.

https://doi.org/10.1081/ERC-120016980

[113] Pihlajoki, M., Gretzinger, E., Cochran, R., Kyronlahti, A., Schrade, A., Hiller, T., et al. (2013) Conditional Mutagenesis of Gata6 in SF1-Positive Cells Causes Gonadal-Like Differentiation in the Adrenal Cortex of Mice. Endocrinology, 154, 1754-1767. https://doi.org/10.1210/en.2012-1892

[114] Nakamura, Y., Xing, Y., Sasano, H. and Rainey, W.E. (2009) The Mediator Complex Subunit 1 Enhances Transcription of Genes Needed for Adrenal Androgen Production. Endocrinology, 150, 4145-4153. https://doi.org/10.1210/en.2009-0006

[115] Kiiveri, S., Siltanen, S., Rahman, N., Bielinska, M., Lehto, V.P., Huhtaniemi, I.T., et al. (1999) Reciprocal Changes in the Expression of Transcription Factors GATA-4 and GATA-6 Accompany Adrenocortical Tumorigenesis in Mice and Humans. Molecular Medicine, 5, 490-501. https://doi.org/10.1007/BF03403542

[116] Viger, R.S., Guittot, S.M., Anttonen, M., Wilson, D.B. and Heikinheimo, M. (2008) Role of the GATA Family of Transcription Factors in Endocrine Development, Function, and Disease. Molecular Endocrinology, 22, 781-798.

https://doi.org/10.1210/me.2007-0513

[117] Bonagura, T.W., Babischkin, J.S., Pepe, G.J. and Albrecht, E.D. (2016) Assessment of Protein Expression by Proximity Ligation Assay in the Nonhuman Primate Endometrium, Placenta, and Fetal Adrenal in Response to Estrogen. Methods in Molecular Biology, 1366, 149-161. https://doi.org/10.1007/978-1-4939-3127-9_12

[118] Lanman, J.T. (1957) The Adrenal Fetal Zone: Its Occurrence in Primates and a Possible Relationship to Chorionic Gonadotropin. Endocrinology, 61, 684-191. https://doi.org/10.1210/endo-61-6-684

[119] Lauritzen, C. and Lehmann, W.D. (1967) Levels of Chorionic Gonadotrophin in the Newborn Infant and Their Relationship to Adrenal Dehydroepiandrosterone. Journal of Endocrinology, 39, 173-182. https://doi.org/10.1677/joe.0.0390173

[120] Seron-Ferre, M., Lawrence, C.C. and Jaffe, R.B. (1978) Role of hCG in Regulation of the Fetal Zone of the Human Fetal Adrenal Gland. The Journal of Clinical Endocrinology \& Metabolism, 46, 834-837. https://doi.org/10.1210/jcem-46-5-834

[121] Abu-Hakima, M., Branchaud, C.L., Goodyer, C.G. and Murphy, B.E. (1987) The Effects of Human Chorionic Gonadotropin on Growth and Steroidogenesis of the Human Fetal Adrenal Gland in Vitro. American Journal of Obstetrics \& Gynecology, 156, 681-687. https://doi.org/10.1016/0002-9378(87)90077-9

[122] Furukawa, S., Hayashi, S., Usuda, K., Abe, M., Hagio, S., Kuroda, Y., et al. (2013) 
Effect of Estrogen on Rat Placental Development Depending on Gestation Stage. Experimental and Toxicologic Pathology, 65, 695-702. https://doi.org/10.1016/j.etp.2012.09.002

[123] Hirst, J.J., West, N.B., Brenner, R.M. and Novy, M.J. (1992) Steroid Hormone Receptors in the Adrenal Glands of Fetal and Adult Rhesus Monkeys. The Journal of Clinical Endocrinology \& Metabolism, 75, 308-314. https://doi.org/10.1210/jc.75.1.308

[124] Albrecht, E.D. and Pepe, G.J. (1987) Effect of Estrogen on Dehydroepiandrosterone Formation by Baboon Fetal Adrenal Cells in Vitro. American Journal of Obstetrics \& Gynecology, 156, 1275-1278. https://doi.org/10.1016/0002-9378(87)90162-1

[125] Albrecht, E.D., Henson, M.C., Walker, M.L. and Pepe, G.J. (1990) Modulation of Adrenocorticotropin-Stimulated Baboon Fetal Adrenal Dehydroepiandrosterone Formation in Vitro by Estrogen at Mid- and Late Gestation. Endocrinology, 126, 3083-3088. https://doi.org/10.1210/endo-126-6-3083

[126] Curran, M.M., Sandman, C.A., Poggi Davis, E., Glynn, L.M. and Baram, T.Z. (2017) Abnormal Dendritic Maturation of Developing Cortical Neurons Exposed to Corticotropin Releasing Hormone (CRH, Insights into Effects of Prenatal Adversity)? PLoS ONE, 12, e0180311. https://doi.org/10.1371/journal.pone.0180311

[127] Ng, M.L., Healy, D.L., Rajna, A., Fullerton, M., O’Grady, C. and Funder, J.W. (1996) Presence of Pro-Opiomelanocortin Peptides and Corticotropin-Releasing Factor in Human Placenta. The Malaysian Journal of Pathology, 18, 59-63.

[128] Frim, D.M., Emanuel, R.L., Robinson, B.G., Smas, C.M., Adler, G.K. and Majzoub, J.A. (1988) Characterization and Gestational Regulation of Corticotropin-Releasing Hormone Messenger RNA in Human Placenta. Journal of Clinical Investigation, 82, 287-292. https://doi.org/10.1172/JCI113585

[129] Petraglia, F., Sawchenko, P.E., Rivier, J. and Vale, W. (1987) Evidence for Local Stimulation of ACTH Secretion by Corticotropin-Releasing Factor in Human Placenta. Nature, 328, 717-719. https://doi.org/10.1038/328717a0

[130] Goland, R.S., Wardlaw, S.L., Stark, R.I., Brown, L.S. and Frantz, A.G. (1986) High Levels of Corticotropin-Releasing Hormone Immunoactivity in Maternal and Fetal Plasma during Pregnancy. The Journal of Clinical Endocrinology \& Metabolism, 63, 1199-1203. https://doi.org/10.1210/jcem-63-5-1199

[131] Goland, R.S., Wardlaw, S.L., Blum, M., Tropper, P.J. and Stark, R.I. (1988) Biologically Active Corticotropin-Releasing Hormone in Maternal and Fetal Plasma during Pregnancy. American Journal of Obstetrics \& Gynecology, 159, 884-890. https://doi.org/10.1016/S0002-9378(88)80162-5 